\title{
BENTUK-BENTUK PENCEGAHAN DAN PENINDAKAN (PEMBERANTASAN) PADA TINDAK PIDANA PENCUCIAN UANG BERDASARKAN UNDANG-UNDANG NOMOR 8 TAHUN 2010
}

\author{
H.M. Ikhwan Rays \\ Fakultas Hukum Universitas Muhammadiyah Luwuk \\ Ikhwanrays63@gmail.com
}

\begin{abstract}
ABSTRAK
Dalam kejahatan pencucian uang terdapat dua bentuk tindakan yang dilarang, yaitu kejahatan menghasilkan uang haram itu sendiri serta pencucian uang haram dengan cara menempatkan, mentransfer, membayarkan, membelanjakan, menghibahkan, menyumbangkan, menitipkan, membawa ke luar negeri, menukarkan atau perbuatan lainnya atas harta kekayaan yang diketahuinya atau patut diduga merupakan hasil tindak pidana dengan maksud untuk menyembunyikan atau menyamarkan asal - usul harta kekayaan sehingga seolah-olah menjadi harta kekayaan yang sah. Bentuk kualifikasi tindak pidana pencucian uang dirumuskan sebagai penempatan harta kekayaan yang diketahuinya atau patut diduganya merupakan hasil tindak pidana ke dalam penyedia jasa keuangan maupun yang lainnya, baik atas nama sendiri atau atas nama orang lain.
\end{abstract}

Kata kunci: Pencegahan, Pemberantasan Pencucian Uang

\begin{abstract}
In money laundering, there are two forms of action that are prohibited, including the crime of making illicit money and laundering illicit money by placing, transferring, paying, spending, donating, depositing, taking abroad, exchanging or other actions for known assets or can reasonably be suspected of being the result of a criminal act with the intention of concealing or disguising the origin of assets so it appear to be legitimate assets. The form of qualification for money laundering is defined as the placement of assets known or reasonably suspected to be the proceeds of crime with financial service providers or others, either on behalf of individuals or on behalf of others.
\end{abstract}

Keywords: Prevention, Eradication of Money Laundering 


\section{Latar Belakang}

Tindak pidana yang sering kali kita dengar melalui media massa atau media elektronik yang seringkali terjadi adalah masalah money laundering ataukasus Pencucian beberapa decade terakhir tindak pidana ini ramai dibicarakan masyarakat maupun aparatur,yang dimaksud dengan pencucian uang (money laundering) itu sendiri adalah suatu upaya perbuatan untuk menyembunyikan atau menyamarkan asal usul uang/dana atau Harta Kekayaan hasil tindak pidana melalui berbagai transaksi keuangan agar uang atau harta kekayaan tersebut tampak seolah-olah berasal dari kegiatan yang sah/legal. Dari berita-berita dimaksud bahwa tindak pidana pencucian uang banyak dilakukan oleh pejabat-pejabatnegara atau biasa disebut dengan kejahatan kerah putih (white collarcrime).

Pencucian uang (money laundering) merupakan bentuk kejahatan kerah putih dimana kejahatan kerah putih ini banyak dan erat kaitannya dengan pencucian uang kejahatankejahatan yang erat kaitannya dengan pencucian uang antara lain Tindak Pidana Korupsi, Tindak Pidana Ilegal
Loging dan masih banyak tindak pidana lain yang bermuara ke Tindak Pidana Pencucian Uang

Korupsi telah merambah keseluruh lini kehidupan masyarakat yang dilakukan secara sistematis, sehingga memunculkan stigma negatif bagi Negara dan bangsa Indonesia di dalam pergaulan masyarakat Internasional.dimana masalah tresebut menjadi menjadi masalah serius bagi bangsa Indonesia, karena Berbagai cara telah di tempuh untuk pemberantasan korupsi bersamaan dengan semakin canggihnya modus operandi tindak pidana korupsi.

Disinyalir oleh Bismar Nasution (2005:1), kekayaan yang didapat dari kejahatan korupsi biasanya oleh pelaku baik perseorangan maupun korporasi tidak langsung digunakan karena ada rasa takut maupun terindikasi sebagai kegiatan pencucian uang. Dalam rangka mengatasi masalah tersebut biasanya para pelaku selalu berupaya untuk menyembunyikan asal-usul harta kekayaan tersebut dengan berbagai cara antara lain berupaya untuk memasukkannya ke dalam sistem keuangan (banking sistem), cara-cara yang ditempuh berupaya 
menyembunyikan atau menyamarkan asal-usul harta kekayaan tersebut dengan maksud untuk menghindari upaya pelacakan oleh aparat penegak hukum yang biasanya diistilahkan dengan pencucian uang atau yang popular dengan sebutan money laundering.

Pengaturan tentang Tindak

Pidana Pencucian Uang pada awalnya diatur dalam Undang-Undang Nomor 15 Tahun 2002 tentang TindakPidana Pencucian Uang (UUTPPU) namun Undang-Undang pertama yang secara spesifik mengatur tentang tindak pidana pencucian uang ternyata tidak mampu memberantas kejahatan ini. Kemudian Undang- Undang ini diubah 1 tahun kemudian dengan dikeluarkannya Undang-Undang Nomor 25 Tahun 2003 tentang Perubahan atas Undang Undang Nomor 15 Tahun 2002 tentang Tindak Pidana Pencucian Uang.

\section{Money Laundring yang} diterjemahkan dengan pencucian uang dalam Undang - Undang No. 15 tahun 2002 sebagaimana telah diubah dalam Undang - Undang No. 25 tahun 2003 tentang Tindak Pidana Pencucian Uang, selanjutnya pada tahun 2010 diadakan penyempurnaan undang-undang ini dengan dikeluarkannyaUndang-Undang

Nomor: 8 Tahun 2010 tentang Pencegahan dan Pemberantasan Tindak Pidana Pencucian Uang.

\section{Pencucian uang (Money}

Laundring) didefenisikan: sebagai perbuatan menempatkan, mentransfer, membayarkan, membelanjakan, menghibahkan, menyumbangkan, menitipkan, membawa ke luar negeri, menukarkan atau perbuatan lainnya atas harta kekayaan yang diketahuinya atau patut diduga merupakan hasil tindak pidana dengan maksud untuk menyembunyikan atau menyamarkan asal-usul harta kekayaan sehingga seolah-olah menjadi harta kekayaan yang sah.

Dalam defenisi tersebut terdapat kata “ seolah-olah". Sehingga walaupun proses pencucian uang dilakukan, namun harta kekayaan yang berasal dari hasil tindak pidana tidak pernah menjadi uang yang syah atau uang yang telah di putihkan. Dengan demikian istilah yang dipakai dan paling tepat adalah "Pencucian Uang" bukan "Pemutihan Uang". Money laundering selalu berkaitan dengan harta kekayaan yang berasal dari tindakpidana, sehingga tidak ada pencucian uang kalau tidak ada 
tindak pidana yang dilakukan (no crime no money laundering ).

Secara umumnya pelaku tindak pidana ini selalu berusaha menyembunyikan atau menyamarkan asal usul harta kekayaan yang diperoleh dari hasil kejahatan, sehingga susah ditelusuri oleh aparat penegak hukum sehingga dengan leluasa memanfaatkan harta kekayaan tersebut baik untuk kegiatan yang sah maupun tidak sah. Karena itu, tindak pidana Pencucian Uang tidak hanya mengancam stabilitas dan integritas sistem perekonomian dan system keuangan, tetapi juga dapat membahayakan sendi-sendi kehidupan bermasyarakat, berbangsa, dan bernegara berdasarkan Pancasila dan UndangUndang Dasar Negara Republik Indonesia Tahun 1945.

Dalam konsep anti pencucian uang, pelaku dan hasil tindak pidana dapat diketahui melalui penelusuran untuk selanjutnya hasil tindak pidana tersebut dirampas untuk negara atau dikembalikan kepada yang berhak.Apabila harta kekayaan hasil tindak pidana yang dikuasai oleh pelaku atau organisasi kejahatan dapat disita atau dirampas, dengan sendirinya dapat menurunkan tingkat kriminalitas. Untuk itu upaya pencegahan dan pemberantasan tindak pidana Pencucian Uang memerlukan landasan hukum yang kuat untuk menjamin kepastian hukum, efektivitas penegakan hukum serta penelusuran dan pengembalian harta kekayaan hasil tindak pidana.

Dalam tindak pidana pencucian uang terdapat dua tindakan, yaitukejahatan menghasilkan uang haram dan pencucian uang haram. Bentuk kualifikasitindak pidana pencucian uang dirumuskan sebagai penempatan hartakekayaan yang diketahuinya atau patut diduganya merupakan hasil tindak pidana ke dalam penyedia jasa keuangan maupun yang lainnya, baik atasnama sendiri atau atas nama orang lain.Berdasarkan ketentuan ini makaadanya perbuatan tindak pidana lain seperti korupsi tidak perlu dibuktikan terlebih dahulu, cukupkalau ada pengetahuan atau dugaan bahwa uang haram tersebut berasal dari perbuatan korupsi, yaitu bila sudah terdapat bukti permulaan yang cukup atas tindak pidana korupsi dimaksud.

Terkait denganTindak Pidana ini terdapat suatu lembaga khusus yangberfungsi sebagai perantara untuk memberikan data transaksi 
mencurigakan kepada aparat penyidik yaitu Pusat Pelaporan dan Analisis TransaksiKeuangan (PPATK). Lembaga ini merupakan lembaga independen yang dibentuk oleh pemerintah dalam rangka melakukan fungsi penyelidikan yaitu mengumpulkan, menyimpan, menganalisis, mengevaluasi informasi transaksi yang dicurigai dan diduga sebagai perbuatan pencucian uang, sebelum informasi itu diteruskan kepada penyidik untuk diproses

Menurut Hikmahanto Juwana (2009:152) dalam prakteknya, pelaku white collar crime cenderung untuk melakukan kejahatan yang sama berulang kali, dengan asumsi bahwa secara ekonomi keuntungan yang akan diperolehnya akan lebih besar daripada biaya yang dikeluarkan. Keuntungan itu diperhitungkan dari kemungkinan biaya bila tertangkap dan terbukti melakukan kejahatan serta besarnya hukuman yang akan dijatuhkan. Dengan demikia atas dasar perhitungan tersebut maka ia akan melakukan kejahatan yang sama untuk waktu-waktu selanjutnya.

Adapunbentuk-bentuk tindaka pidana lain yang erat kaitannya denag Kejahatan Pencucian Uang yang sering kita ikuti di berbagai media dimana para pelakunya yang sedang menjalani proses pemeriksaan ataupun penghukuman antara lain: penyalahgunaan narkotika, terorisme, korupsi, penyuapan ataugratifikasi, walaupun tidak menutup kemungkinan dari hasil tindak pidana lainnya.

Terkait tindak pidana ini Pemerintah mulai memikirkan bahwa upaya pemberantasan saja tidak cukup untuk menangani permasalahan kejahatan ini. Oleh karena itu dibutuhkan upaya preventif (pencegahan) yang berguna untuk mencegah tindak pidana ini agar jangan sampai terjadi terus menerus. Dalam rangka melakukan upaya-upaya preventif dimaksud maka pemerintah dalam kurun waktu yang relatif singkat telah mengeluarkan beberapa produk undang-undang dalam rangka mengurangi sekaligus mencegah terjadinya pencucian uang, undangundang dimaksud yaitu: Undang-Undang Nomor 8 Tahun 2010 tentang Pencegahan dan Pemberantasan Tindak Pidana Pencucian. Undang - Undang ini secara otomatis mencabut UndangUndang Nomor 15 Tahun 2002 tentang Tindak Pidana Pencucian Uang dan Undang - Undang Nomor: 25 Tahun 
2003 tentang perubahan atas Undang Undang Nomor: 15 Tahun 2003 tentang Tindak Pidana Pencucian Uang

\section{Metode Penelitian}

Jenis atau pendekatan yang akan digunakan dalam penelitian ini adalah pendekatan yuridis normatif sehingga langkah-langkah dalam penelitian ini menggunakan logika yuridis. Ronny Hanitijo Soemitro berpendapat (1991:44), Pendekatan terhadap hukum yang normatif mengidentifikasikan dan mengkonsepsikan hukum sebagai norma, kaidah, peraturan, Undang-undang yang berlaku pada suatu waktu dan tempat tertentu sebagai produk dari suatu kekuasaan negara tertentu yang berdaulat. Penelitian ini menggunakan pendekatan yuridis normatif bertujuan untuk mengkaji bagaimana pencegahan dan pemberantasan tindak pidana pencucian uang berdasarkan Undangundang Nomor 8 tahun 2010

\section{Hasil dan Pembahasan}

Bentuk Pencegahan dan

Pemberantasan Tindak Pidana

Pencucian Uang Sebagaimana diatur dalam Undang-Undang Nomor 8 Tahun 2010.

Sebelum berlakunya UndangUndang Nomor: 8 Tahun 2010 terdapat beberapa UU tentang TPPU (UU Nomor 15 Tahun 2002, UU Nomor 25 Tahun 2003) dimana saat berlakunya kedua UU ini lebih banyak penekakan pada bentuk pemberantasan/penindakan sehingga tindak pidana ini semakin bertambah jumlahnya. Namun dengan dikeluarkannya Undang-Undang Nomor 8 Tahun 2010, Pemerintah disamping melakukan upaya pemberantasan dan penindakan dilakukan pula upaya pencegahan (preventif),

Untuk lebih jelasnya penulis mencoba mengelompokkan bentukbentuk tindakan yang merupakan upaya pencegahan (preventif) yang diatur dalam UU Nomor 8 Tahun 2010 adalah sebagai berikut:

\section{Pokok-Pokok UU Nomor 8 Tahun 2010}

\section{a. Substansi Pengaturan \\ Undang-Undangini}

merupakan suatu aturan yang diharapkan untuk mewujudkan aturan yang akan digunakan untuk mengantisipasi berbagai pola kejahatan yang mengarah pada kegiatan pencucian uang. Karena sasaran dari UU ini adalah dalam rangka mencegah dan memberantas sistem atau proses pencucian uang 
dalam bentuk placement, layering dan integration. dimana sasaran utama dalam kegiatan pencucian uang adalah lembaga keuangan bank maupun non bank, maka sasaran pengaturan dari UU No. 8 Tahun 2010 ini meliputi peranan-peranan aktif dari lembaga-lembaga ini untuk mengantisipasi kejahatan pencucian uang.

Terminologi Lembaga keuangan bank dan non bank dalam pengaturan UU Nomor 8 Tahun 2010disebut dengan istilah Penyedia Jasa Keuangan. Penyedia Jasa Keuangan diartikan sebagai penyedia jasa dalam bidang keuangan atau jasa lainnya yang terkait dengan keuangan termasuk tetapi tidak terbatas pada bank, lembaga pembiayaan, perusahaan efek, pengelola reksa dana, kustodian, wali amanat, lembaga penyimpanan dan penyelesaian, pedagang valuta asing, dana pensiun, perusahaan asuransi dan kantor Pos. Kemudian banyak sistem penanganan kejahatan dalam UU No. 8 Tahun 2010 ini yang diproses dengan hukum acara pidana yang bersifat khusus, karena memang asas-asas hukumnya bersifat lex specialis.

\section{b. Undang-Undang Nomor 8 Tahun 2010 sebagai Lex specialis}

Dalam Pasal 68 UU ini ditentukan bahwa penyidikan, penuntutan dan pemeriksaan, dilakukan berdasarkan ketentuan KUHAP, kecuali ditentukan lain dalam UU ini. Dari pengaturan ini tampak bahwa para pembuat UU menginginkan UU Nomor 8 Tahun 2010 ini lebih banyak disesuaikan dengan sifat perkembangan masalah kejahatan pencucian uangyang memiliki karakter yang lebih khusus dari masalah yang diatur oleh perundang-undangan lain. Dengan demikian tampak bahwa UU ini memanglah memiliki sifat lex specialis dan prinsip-prinsip dalam UU ini bisa menjadi pengecualian terhadap ketentuan-ketentuan UU lain berdasarkan prinsip lex specialis derogate legi lex generalis.

\section{c. Kualifikasi Perbuatan Pidana dan Ancaman Hukuman}

Pidana yang diancamkan kepada yang melakukan percobaan, pembantuan atau permufakatan jahat 
dalam pencucian uang disamaratakan dengan ancaman pidana terhadap pelaku pidana yang telah selesai dilakukan sebagaimana diatur dalam Pasal 3, Pasal 4, dan Pasal 5 UU Nomor: 8 Tahun 2010. Dengan kata lain ancaman sanksi yang diancamkan pada Pasal 3, Pasal 4, dan Pasal 5 dengan yang terdapat pada Pasal 10 tidak dibedakan.

Pengaturan dalam Pasal 10 UU Nomor 8 tahun 2010 ini berbeda atau menyimpang secara prinsipil dengan ketentuan dalam KUHP, karena pada pasal 53 dan 57 KUHP menentukan bahwa kualifikasi percobaan, pembantuan atau permufakatan jahat dibedakan kualifikasinya dengan perbuatan pidana yang telah selesai dilakukan.

\section{d. Fungsi PPATK Yang diperluas}

Dalam UU Nomor 8 Tahun 2010 ini fungsi PPATK menjadi lebih luas dibandingkan undang-undang sebelumnya dimana fungsinya antara lain :

1) Pencegahan dan pemberantasan tindak pidana pencucian uang.

2) Pengelolaan data dan informasi yang diperoleh PPATK.
3) Pengawasan terhadap kepatuhan pihak pelapor.

4) Analisis atau pemeriksaan laporan dan informasi transaksi keuangan yang berindikasi tindak pidana pencucian uang dan/atau tindak pidana lain.

Dengan adanya fungsi-fungsi tersebut maka kewenangan PPATK menjadi semakin luas guna menjalankan fungsi-fungsinya tersebut.

\section{e. Perintah Pemblokiran Penyidik,Penuntut Umum dan Hakim}

Pemblokiran dapat dilakukan terhadap harta kekayaan tersangka atau terdakwa, dapat dilakukan jika sudah diketahui atau patut diduga harta tersebut adalah hasil kejahatan. Pasal 71 UU Nomor 8 Tahun 2010 menentukan bahwa Penyidik, Penuntut Umum dan Hakim berwenang untuk memerintahkan Penyedia Jasa Keuangan untuk melakukan pemblokiran terhadap harta kekayaan setiap orang yang telah dilaporkan oleh PPATK kepada penyidik yang diketahui atau patut diduga merupakan hasil suatu tindak pidana. 


\section{f. Alat Bukti dan Cyberlaundering}

Dalam Pasal 73 UU Nomor 8 Tahun 2010 yang merupakan alat bukti dalam pemeriksaan terdapat perluasan alat bukti, yaitu:

1) Alat bukti sebagaimana dimaksud dalam Hukum Acara Pidana.

2) Alat bukti lain berupa informasi yang diucapkan,dikirimkan, diterima, atau disimpan secara elektronik dengan alat optik atau alat yang serupa optik dan dokumen; dan

3) Dokumen sebagaimana dimaksud dalam pasal 1 angka 16

Adapun ketentuan dalam Pasal 1 angka 16 UU No. 8 Tahun 2010 berbunyi "Dokumen adalah data, rekaman, atau informasi yang dapat dilihat, dibaca, dan/atau didengar, yang dapat dikeluarkan dengan atau tanpa bantuan suatu sarana, baik yang tertuang di atas kertas, benda fisik apapun selain kertas, atau yang terekam secara elektronik, termasuk tapi tidak terbatas pada:

a. tulisan, suara atau gambar

b. peta, rancangan, foto atau sejenisnya; c. huruf, tanda, angka, simbol, atau perforasi yang memiliki makna atau dapat dipahami oleh orang yang mampu membaca atau memahaminya."

Alat bukti yang dipergunakan dalam pemeriksaan suatu tindak pidana pencucian uang menurut Pasal 73 UU No. 8 Tahun 2010 ini memang sangat beragam. Hal ini jelas merupakan suatu kebutuhan dalam pemberantasan pencucian uang karena masalah pencucian uang merupakan masalah yang sangat kompleks karena modusdan sistem kejahatan yang dipraktekan oleh para pelaku pencucian uang sudah menggunakan alat-alat berteknologi tinggi.

\section{g. Penentuan Pidana Minimum dan Maksimum}

Berbeda dengan KUHP, UU Nomor 8 Tahun 2010 ini menentukan ancaman pidana secara minimum serta maksimum. Hal ini dapat kita lihat antara lain pada Pasal 3, Pasal 4, Pasal 5, dan Pasal 7. UU ini menentukan ancaman pidana penjara paling singkat 5 tahun dan paling lama 20 tahun dan denda paling sedikit Rp. 1.000.000.000 (satu miliar 
rupiah) dan paling banyak $\mathrm{Rp}$. 100.000.000.000. (seratus milyar rupiah)

\section{h. Peradilan In Absentia}

Kekhususan hukum acara pidana yang dipergunakan oleh UU Nomor 8 Tahun 2010 ini ialah diterapkannya sistem peradilan in absentia.Peradilan in absentia ialah peradilan yang dilakukan dengan suatu putusan pengadilan dimana terdakwa tidak hadir meskipun telah dipanggil secara sah menurut ketentuan yang berlaku.Pengaturan sistem peradilan in absentia yang diatur dalam pasal 79 UUPU ini bermaksud agar peradilan dapat berjalan dengan lancar walaupun tanpa kehadiran terdakwa. Disamping itu adalah untuk menyelamatkan harta dari hasil kejahatan yang dilakukan oleh terdakwa.

\section{i. Pembuktian Terbalik}

UU Nomor8 Tahun 2010 menganut pula sistem pembuktian terbalik, dimana terdakwa sendirilah yang diwajibkan untuk membuktikan bahwa dirinya tidak bersalah. Ketentuan dalam Pasal 77 menyatakan: "untuk kepentingan pemeriksaan di sidang pengadilan, terdakwa wajib membuktikan bahwa harta kekayaannya bukan merupakan hasil tindak pidana."

\section{j. Harta Terdakwa Yang Meninggal Sebelum Putusan Hakim}

Dalam Pasal 79 ayat (4) UU Nomor 8 Tahun 2010 ini dinyatakan bahwa jika terdakwa meninggal dunia sebelum putusan hakim dijatuhkan, dan terdapat bukti-bukti meyakinkan bahwa terdakwa melakukan tindak pidana tersebut, maka hakim dapat membuat penetapan tentang harta terdakwa yang sudah disita untuk dirampas dan dimiliki oleh negara. Ketentuan pada pasal 79 ayat (4) ini sangat bertentangan dengan asas presumption of innocence, dimana seseorang tidak dapat dinyatakan bersalah sebelum ada keputusan hakim yang menyatakan bahwa ia bersalah atas dakwaan yang didakwakan kepadanya.

2. Tindak Pidana Pencucian Uang dan Tindak Pidana Asal

Berbeda dengan UU No.15 Tahun 2002, dalam UU No. 25 Tahun 2003 terdapat pasal yang menjelaskan mengenai pengertian dari pencucian uang,sedangkan di dalam 
Dibanding dengan UU TPPU sebelumnya (UU Nomor: 15 Tahun 2002 dan UU Nomor 25 Tahun 2003) maka dalam UU Nomor: 8 Tahun 2010 definisi Pencucian Uang diperluas kembali menjadi berbunyi "Pencucian uang adalah segala perbuatan yang memenuhi unsurunsur tindak pidana sesuai dengan ketentuan dalam Undang-Undang ini”. Dalam UU Nomor: 15 Tahun 2002, pengertian pencucian uang tidak dijelaskan secara eksplisit akan tetapi diberikan arti kategorisnya saja (pada pasal 2 UU No.15 Tahun 2002). Adapun pengertian dari pencucian uang sebagaimana yang dijelaskan dalam pasal 1 ayat (1) UU No.25 Tahun 2003 adalah:

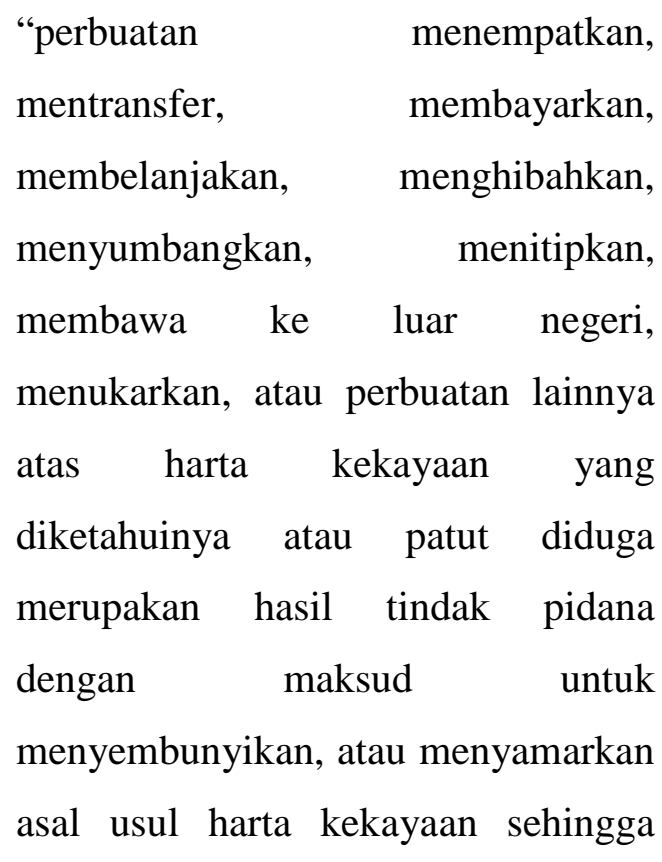

seolah-olah menjadi harta kekayaan yang sah."

Pada Pasal 2 UU Nomor:8 Tahun 2010 diatur mengenai jenisjenis tindak pidana yang hasil dari tindakan tersebut merupakan harta kekayaan sebagaimana yang dimaksud dalam UU Nomor 8 Tahun 2010. Hal ini bentuk merupakan perluasan dari UU Pencucian Uang UU Nomor 8 Tahun 2010, karena tindak pidana ini terkait dengan tindak pidana lainnya yang disebut sebagai predicate offences.

Adapun yang tercantum dalam pasal 2 UU No 8 Tahun 2010 adalah: (1) Hasil Tindak Pidana adalah Harta Kekayaan yang diperoleh dari tindak pidana:

a. korupsi; b. penyuapan;c. narkotika d. psikotropika; e. penyelundupan tenaga kerja; f. penyelundupan migran; g. di bidang perbankan; h. di bidang pasar modal; i. di bidang perasuransian; j. kepabeanan; k.cukai; 1. perdagangan orang; $m$. perdagangan senjata gelap; n.terorisme; o. penculikan; p. pencurian; q. penggelapan; r.penipuan; s. pemalsuan uang; t. 
perjudian; u. prostitusi; v. di bidang perpajakan; w. di bidang kehutanan; $\mathrm{x}$. di bidang lingkungan hidup; y. di bidang kelautan dan perikanan; atau z. tindak pidana lain yang diancam dengan pidana penjara 4 (empat) tahun atau lebih, yang dilakukan di wilayah Negara Kesatuan Republik Indonesia atau di luar wilayah Negara Republik Indonesia dan tindak pidana tersebut juga merupakan tindak pidana menurut hukum Indonesia.

(2) Harta Kekayaan yang diketahui atau patut diduga akan digunakan dan/atau digunakan secara langsung atau tidak langsung untuk kegiatan terorisme, organisasi teroris, atau teroris perseorangan disamakan sebagai hasil tindak pidana sebagaimana dimaksud pada ayat (1) huruf $n$.

Berkaitan dengan tindak pidana pencucian uang sebagaimana diatur di dalam UU No. 8 Tahun 2010, yaitu:

1) Pasal 3: Perbuatan yang dengan sengaja menempatkan, mentransfer, mengalihkan, membelanjakan, membayarkan, menghibahkan, menitipkan, membawa ke luar negeri, mengubah bentuk, menukarkan dengan mata uang atau surat berharga atau perbuatan lain atas kekayaan yang diketahuinya atau patut diduganya merupakan hasil hasil tindak pidana sebagaimana dimaksud dalam Pasal 2 ayat (1) dengan tujuan menyembunyikan atau menyamarkan asal usul Harta Kekayaan.

2) Pasal 4: Perbuatan yang menyembunyikan atau menyamarkan asal usul, sumber, lokasi, peruntukan, pengalihan hak-hak, atau kepemilikan yang sebenarnya atas harta kekayaan yang diketahuinya atau patut diduganya merupakan hasil tindak pidana sebagaimana dimaksud dalam Pasal 2 ayat (1).

3) Pasal 5: Perbuatan yang menerima atau menguasai penempatan, pentransferan, pembayaran, hibah, sumbangan, penitipan, penukaran atau menggunakan Harta kekayaan yang diketahuinya atau patut diduganya merupakan hasil 
tindak pidana sebagaimana dimaksud dalam Pasal 2 ayat (1).

Ketentuan di Pasal 5 ayat (1)

UU No: 8 Tahun 2010 dikecualikan bagi pihak pelapor yang melaksanakan kewajiban pelaporan.Untuk tindak pidana pencucian uang sebagaimana dimaksud di dalam Pasal 3, Pasal 4, dan Pasal 5 UU Nomor: 8 Tahun 2010 dilakukan oleh Korporasi, maka pidana dijatuhkan terhadap Korporasi dan/atau Personil Pengendali Korporasi.Di luar pengaturan Pasal 2, Pasal 3, Pasal 4, dan Pasal 5 terdapat pasal-pasal lain yang mengatur mengenai tindak pidana yang berkaitan dengan tindak pidana pencucian uang. Tindak pidana lain yang berkaitan dengan tindak pidana pencucian uang diatur pada Pasal 11, Pasal 12, Pasal 14, Pasal 15, dan Pasal 16 UU Nomor: 8 Tahun 2010.

\section{Pusat Pelaporan dan Analisis} Transaksi Keuangan

PPATK memiliki

kelembagaan yang independen, yang bebas dari campur tangan yang bersifat politik seperti Lembaga Negara, Penyelenggara Negara dan pihak lainnya. PPATK dalam melaksanakan tugasnya diwajibkan untuk menolak campur tangan dari pihak manapun. Prinsip ini dapat ditafsirkan dari ketentuan pasal 18 ayat (2) dan pasal 25 ayat (1) UU No. 15 Tahun 2002 yang menyatakan: Pasal 18 ayat (2) "PPATK adalah lembaga yang independen dalam melaksanakan tugas dan wewenangnya." Sedangkan Pasal 25 ayat (1) "Setiap pihak tidak boleh melakukan segala bentuk campur tangan terhadap pelaksanaan tugas dan kewenangan PPATK."

Pada penjelasan Pasal 25 ayat (2) UU Nomor 15 Tahun 2002 menyatakan bahwa yang dimaksud dengan "independen" adalah bebas dari intervensi pihak manapun. Sifat independen dari PPATK ini juga ditegaskan dalam ayat berikutnya bahwa PPATK, yang diwakili oleh kepala dan wakil kepalanya, untuk menolak campur tangan pihak lain.Adanya ketentuan-ketentuan ini maka tidak dimungkinkan adanya campur tangan eksternal dalam pelaksanaan tugas dan kewenangan PPATK.

$\begin{array}{ccc} & \text { PPATK merupakan } & \text { suatu } \\ \text { lembaga } & \text { independen } & \text { yang }\end{array}$


bertanggungjawab langsung kepada Presiden merupakan Financial Intelligent Unit dengan model administratif (administrative model). Model administratif ini lebih banyak berfungsi sebagai perantara antara masyarakat atau industri jasa keuangan dengan institusi penegak hukum.Hasil analisis yang dilakukan terlebih dahulu dahulu oleh lembaga ini selanjutnya dilaporkan ke institusi penegak hukum, yaitu Kepolisian dan Kejaksaan.

Sebagai suatu financial intelligent unit akan melakukan beberapa tugas dan wewenang, yaitu tugas pengaturan sebagai regulator, melakukan kerjasama dalam rangka penegakkan hukum, bekerjasama dengan sektor keuangan, menganalisa laporan yang masuk, melakukan pengamanan terhadap seluruh data dan aset yang ada, melakukan kerjasama internasional dan fungsi administrasi umum.

Dalam rangka melaksanakan perannya sebagai financial intelligent unit dalam usaha pencegahan dan pemberantasan pencucian uang di Indonesia, PPATK diberikan tugas dan wewenang oleh UU Nomor: 8
Tahun 2010 diatur dalam Pasal 39, dimana tugas utama PPATK adalam mencegah dan memberantas tindak pidana pencucian uang. Sedangkan fungsi PPATK sebagaimana diatur dalam Pasal 40 UU Nomor 8 Tahun 2010 antara lain adalah:

a. Pencegahan dan pemberantasan tindak pidana pencucian uang;

b. Pengelolaan data dan informasi yang diperoleh PPATK;

c. Pengawasan terhadap kepatuhan pihak pelapor; dan

d. Analisis atau pemeriksaan laporan dan informasi Transaksi Keuangan yang berindikasi tindak pidana pencucian uang dan/atau tindak pidana lain sebagaimana dimaksud dalam Pasal 2 ayat (1).

Sementara dalam Pasal 41 UU Nomor: 8 Tahun 2010, PPATK mempunyai kerwenangan sbb:

a. meminta dan mendapatkan data dan informasi dari instansi pemerintah dan/atau lembaga swasta yang memiliki kewenangan mengelola data dan informasi, termasuk dari instansi pemerintah dan/atau lembaga 
swasta yang menerima laporan dari profesi tertentu;

b. menetapkan pedoman identifikasi Transaksi Keuangan

Mencurigakan;

c. mengoordinasikan upaya pencegahan tindak pidana Pencucian Uang dengan instansi terkait;

d. memberikan rekomendasi kepada pemerintah mengenai upaya pencegahan tindak pidana Pencucian Uang;

e. mewakili pemerintah Republik Indonesia dalam organisasi dan forum internasional yang berkaitan dengan pencegahan dan pemberantasan tindak pidana Pencucian Uang;

f. menyelenggarakan program pendidikan dan pelatihan antipencucian uang; dan

g. menyelenggarakan sosialisasi pencegahan dan pemberantasan tindak pidana Pencucian Uang.

Berdasarkan ketentuan Pasal 42 UU Nomor 8 Tahun 2010, PPATK berwenang menyelenggarakan sistem informasi. Yang dimaksud dengan sistem informasi sebagaimana dijabarkan dalam penjelasan Pasal 42 UU No. 8 Tahun 2010 antara lain:

a. Membangun, mengembangkan, dan memelihara sistem aplikasi;

b. Membangun, mengembangkan, dan memelihara infrastruktur jaringan komputer dan basis data;

c. Mengumpulkan, mengevaluasi data dan informasi yang diterima oleh PPATK secara manual dan elektronik;

d. Menyimpan, memelihara data dan informasi ke dalam basis data;

e. Menyajikan informasi untuk kebutuhan analisis;

f. Memfasilitasi pertukaran informasi dengan instansi terkait baik dalam negeri maupun luar negeri; dan

g. Melakukan sosialisasi penggunaan sistem aplikasi kepada pihak pelapor.

Pelaksanakan fungsi pengawasan terhadap kepatuhan pihak pelapor sebagaimana diatur di dalam Pasal 43 UU Nomor 8 Tahun 2010, PPATK berwenang:

a. Menetapkan ketentuan dan pedoman tata cara pelaporan bagi pihak pelapor; 
b. Menetapkan kategori pengguna jasa yang berpotensi melakukan tindak pidanapencucian uang;

c. Melakukan audit kepatuhan atau audit khusus;

d. Menyampaikan informasi dari hasil audit kepada lembaga yang berwenang melakukan pengawasan terhadap pihak pelapor;

e. Memberikan peringatan kepada pihak pelapor yang melanggar kewajiban pelaporan;

f. Merekomendasikan kepada lembaga yang berwenang mencabut izin usaha pihak pelapor; dan

g. Menetapkan ketentuan pelaksanaan prinsip mengenali pengguna jasa bagi pihak pelapor yang tidak memiliki lembaga pengawas dan pengatur.

$$
\text { Selanjutnya dalam }
$$

melaksanakan fungsi analisis atau pemeriksaan laporan dan informasi, dalam ketentuan Pasal 44 UU No. 8 Tahun 2010 diatur bahwa PPATK dapat:

a. Meminta dan menerima laporan dan informasi dari pihak pelapor; b. Meminta informasi kepada instansi atau pihak terkait;

c. Meminta informasi kepada pihak pelapor berdasarkan pengembangan hasil analisis PPATK;

d. Meminta informasi kepada pihak pelapor berdasarkan permintaan dari instansi penegak hukum atau mitra kerja di luar negeri;

e. Meneruskan informasi dan/atau hasil analisis kepada instansi peminta, baik di dalam maupun di luar negeri;

f. Menerima laporan dan/atau informasi dari masyarakat mengenai adanya dugaan tindak pidana pencucian uang;

g. Meminta keterangan kepada pihak pelapor dan pihak lain yang terkait dengan dugaan tindak pidana pencucian uang;

h. Merekomendasikan kepada instansi penegak hukum mengenai pentingnya melakukan intersepsi atau penyadapan atas informasi elektronik dan/atau dokumen elektronik sesuai dengan ketentuan peraturan perundang-undangan; 
i. Meminta penyedia jasa keuangan untuk menghentikan sementara seluruh atau sebagian transaksi yang diketahui atau dicurigai merupakan tindak pidana;

j. Meminta informasi perkembangan penyelidikan dan penyidikan yang dilakukan oleh penyidik tindak pidana asal dan tindak pidana pencucian uang;

k. Mengadakan kegiatan administratif lain dalam lingkup tugas dan tanggung jawab sesuai dengan ketentuan undang-undang ini; dan

1. Meneruskan hasil analisis atau pemeriksaan kepada penyidik.

Dari tugas dan wewenang yang di atur dalam ketentuan tersebut di atas, terdapat dua tugas PPATK yang sangat menonjol dalam kaitannya dengan usaha pencegahan dan pemberantasan pencucian uang di Indonesia, yaitu:

pertama adalah untuk mendeteksi terjadinya tindak pidana pencucian uang, dan yang kedua adalah tugas untuk membantu penegakan hukum yang berkaitan dengan kegiatan pencucian uang dan juga tindak pidana yang melahirkannya (predicate crimes).

Sebagai lembaga independen yang mempunyau tugasdan tujuan untuk mencegah dan memberantas kegiatan pencucian uang di Indonesia, PPATK akan bekerja sama dengan berbagai pihak, selain dengan Kepolisian dan Kejaksaan sebagai penegak hukum yang berwenang melakukan penyidikan dan penuntutan dalam tindak pidana pencucian uang, PPATK juga akan bekerjasama dengan Bank Indonesia, Dirjen Pajak, Dirjen Bea Cukai, Badan Pengawas Pasar Modal, Departemen Keuangan, masyarakat dan lembaga-lembaga lain baik dari dalam maupun luar negeri. Begitu banyaknya pihak yang terlibat dalam usaha pencegahan dan pemberantasan pencucian uang di Indonesia, dapat dipahami bahwa Tindak Pidana ini merupakan suatu ancaman yang sangat berbahaya sehingga dibutuhkan kerjasama dari banyak pihak untuk menhagatsinya

Adapun upaya-upaya untuk pemberantasan (penindakan) TPPU pada UU Nomor 8 Tahun 2010 dapat dilihat pada poin berikut 
4. Unsur-Unsur Pokok Tindak Pidana Pencucian Uang pada UU Nomor 8 Tahun 2010

Berdasarkan ketentuan Pasal

$3,4,5,6,7,8,9$ dan 10 UU Nomor 8

Tahun 2010, yang termasuk ke dalam

unsur unsur tindak pidana pencucian uang adalah :

Pertama, Setiap orang baik orang perseorangan maupun korporasi dan personil pengendali korporasi.

Kedua, menempatkan, mentransfer, mengalihkan, membelanjakan, membayarkan, menghibahkan, menitipkan, membawa ke luar negeri, mengubah bentuk, menukarkan dengan mata uang atau surat berharga atau perbuatan lain atas Harta Kekayaan yang diketahuinya atau patut diduganya merupakan hasil tindak pidana sebagaimana dimaksud dalam Pasal 2 ayat (1) UU No 8 Tahun 2010.

Ketiga, menerima atau menguasai penempatan, pentransferan,

pembayaran, hibah, sumbangan, penitipan, penukaran, atau menggunakan Harta Kekayaan yang diketahuinya atau patut diduganya merupakan hasil tindak pidana sebagaimana dimaksud dalam Pasal 2 ayat (1) UUN0 8 Tahun 2010.

Keempat, bertujuan menyembunyikan atau menyamarkan asal usul, sumber, lokasi, peruntukan, pengalihan hak-hak, atau kepemilikan yang sebenarnya atas Harta Kekayaan yang diketahuinya atau patut diduganya merupakan hasil tindak pidana sebagaimana dimaksud dalam Pasal 2 ayat (1) UU No 8 tahun 2010. Adapun sanksi hukum yang dapat dikenakan kepada pelakau Tindak Pidana Pencucian Uang berupa pidana penjara dan pidana denda (diatur dalam ketentuan Pasal 3, Pasal 4, Pasal 5 ayat (1), Pasal 6 ayat (1) dan (2), Pasal 7 ayat (1) dan (2), Pasal 8, Pasal 9 ayat (1) dan (2) dan Pasal 10 UU Nomor: 8 tahun 2010.

\section{Kesimpulan}

Kesimpulan yang dapat ditarik dengan berlakunya Undang-Undang Nomor 8 Tahun 2010 tentang Pencegahan dan Pemberantasan Tindak Pidana Pencucian Uang yaknipada Undang-Undang ini nampak adanya prinsip-prinsip pencegahan dan pemberantasannya; seperti pada bentuk pencegahan antara lain: kualifikasi 
perbuatan pidana dan ancaman hukumannya, perintah pemblokiran dana oleh penyidik, penuntut umum dan hakim, penetapan pidana minimum dan maksimum, peradilan in absensia, pembuktian terbalik, harta terdakwa yang meninggal sebelum putusan hakim dan Tindak Pidana Pencucian Uang dan penetapan tindak pidana asal. Begitu pula pada bentuk pemberantasan dimana kualifikasi TPPU telah ditentukan secara limitatif pada Pasal - Pasal 3, 4, 5, 6, 7, 8, 9 dan 10 UU No: 8 Tahun 2010

\section{Daftar Pustaka}

Adrian Sutedi. 2007.Hukum Perbankan: Suatu Tinjauan Pencucian Uang, Merger,Likuidasi, Dan Kepailitan.Jakarta: Sinar Grafika.

Arief Amrullah. 2004.Money Laundering (Tindak Pidana Pencucian Uang). Malang.Bayu Media.

Bambang Sunggono.1997. Metodologi Penelitian Hukum. Jakarta. PT Raja Grafindo Persada

Burhan Ashhofa. 1998. Metode Penelitian Hukum. Jakarta. Rineka Cipta

Bismar Nasution. 2005. Rezim Anti money Laundring. Bandung.
Penerbit Books Terrance \& Library.

Direktorat Hukum Bank Indonesia.2001.Kegiatan Money Laundering. Jakarta

Edwin O. Sutherland. 1949. White Collor Crime, New York: Dryden.

E.R Burke. 2001. Tracing Illegal Proceeds Work Book, (Investigation Training Institute)

Yunus Husein.2002. “Upaya Penanganan Tindak Pidana Pencucian Uang (Money Laundering)".Medan. Universitas Sumatera Utara (USU)

Hikmahanto Juwana.2009.Bahan Kuliah Magister Hukum Teori hukum. Jakarta UI Press

N.H.T. Siahaan, 2005, Pencucian Uang dan Kejahatan Perbankan, Jakarta : PustakaSinar Harapan.

Soerjono Soekanto. 1986.Pengantar Penelitian Hukum, cetakan 3,Jakarta. Penerbit Universitas Indonesia

Soerdjono Soekanto. 2006. Sosiologi Suatu Pengantar. Jakarta. PT Raja Grafindo Persada

Sutan Remy Sjahdeini, 2004, Seluk Beluk Tindak Pidana Pencucian 
Uang danPembiayaan Terorisme, Sumber Lainnya:

Jakarta. PT Pustaka Utama Grafiti. APG, "History and Background", Ronny Hanitijo Soemitro.1991. http://www.apgml.org/content/hist Metodologi Penelitian Hukum dan oryand backgroud.

Jurimetri. Bandung. Refika http://pembaharuan-

Aditama

Perundang-Undangan:

Undang-Undang Nomor: 8 Tahun 2010 hukum.blogspot.com/2009/02/penc ucian-uang-sebagaikejahatan_03.html?=1

tentang Tindak Pidana Pencucian Uang 